\title{
The Comparison of Regeneration from Root Node Explants in Solanaceae
}

\author{
Muhammet Çağrı Oğuz', Merve Dilek Karataş², Ezgi Oğuz \\ Muhammad Mujtaba ${ }^{1}$, Serdar Altintaş ${ }^{3}$, Ali Ergül ${ }^{1 *}$ \\ ${ }^{1}$ Biotechnology Institute, Ankara University, Ankara 06110, Turkey \\ ${ }^{2}$ Van Yüzüncü Yıl University, Department of Agricultural Biotechnology, Van, Turkey \\ ${ }^{3}$ Siirt University Agricultural Biotechnology Department, Siirt, Turkey
}

Received: 8 September 2020

Accepted: 13 November 2020

\begin{abstract}
Tissue culture techniques in tomato, pepper and eggplant are important for the development of disease-resistant and high yielding varieties, which require a suitable regeneration protocol. Although shoot regeneration has been achieved by using different explants and cytokinin doses in Solanaceae species, very few studies have reported in vitro regeneration using root tissues. The current study is the first report to compare direct shoot regeneration capabilities using root node explants in three Solanaceae species (tomato, pepper, and eggplant) under three cytokinins (BAP, TDZ, and GA3) hormone. Plantlets were regenerated from the root node explants of tomato, pepper and eggplant in the media containing $0,0.5,1,1.5$ and $2 \mathrm{mg} / \mathrm{L}$ of BAP, TDZ and GA3. Results revealed that the shoot regeneration of root node explants varied according to the species, cytokinins (BAP, TDZ and GA3) and doses of hormones. Among the species, the best shoot regeneration was observed in tomato followed by eggplant and pepper plants. While the shoot length was statistically significant in tomato, it was observed to be insignificant in pepper and eggplant. The highest number of root regeneration and root length was observed in tomatoes. The results obtained from the study will contribute to the development of successful/reproducible tissue culture protocols from roots node explants.
\end{abstract}

Keywords: Solanaceae, root node explants, regeneration, tomato, eggplant, pepper

\section{Introduction}

Successful/reproducible tissue culture protocols are required to determine the action mechanism of plant hormones on cellular differentiation, organ formation, somatic embryogenesis, direct regeneration, secondary metabolite/alkaloid production in plant

*e-mail: ergul@ankara.edu.tr tissue during regeneration [1-3]. Besides, successful in vitro regeneration optimizations are an important step for studying somaclonal variations, in vitro mutations, herbicide tolerance, diploid induction; secondary metabolite production, economically important transgenic plant production and the development of somatic hybrids require an effective regeneration protocol [4-6]. Regeneration capability of different tissues depends on species, cultivar and genotype, cellular structure and cellular action mechanisms of 
plant hormones [7]. Like other families, in Solanaceae, there is a huge potential in terms of protocol optimization for regeneration with maximum yield (shoots and roots).

Solanaceae contains about 4000 species of economically and ecologically important family presenting a large number of model plants, genetic resources, secondary metabolites, medically and chemically active substances [8]. In terms of environmental importance on agriculture, it has been reported that secondary metabolites and plant extracts obtained from plants belonging to the family Solanaceae can provide a protective effect against bacteria, fungi, harmful plant insects and abiotic damages [9, 10]. On the other hand; biotechnological studies in Solanaceae species were primarily focused on tomato and wild relatives (Solanum genus, former genus Lycopersicon) followed by eggplant (genus Solanum) and pepper species (genus Capsicum) [11, 12]. In pepper (Capsicum annum) the regeneration experiments have been carried out following different tissue culture techniques such as direct organogenesis, axillary proliferation, axillary meristem, indirect somatic embryogenesis using zygotic embryo, cotyledon, hypocotyl, and leaf explants [13-18]. However, no study has been reported regarding the regeneration in pepper using root as explant.

As in other plants, in tomato (Solanum lycopersicum), abiotic stresses such as drought, salinity, and biotic environmental stresses like pathogens, insects and fungi are the main limiting factors in a plant's growth and productivity [19]. Tomato tissue culture studies which are important for biotechnological applications such as the determination of molecular mechanisms of these stresses and obtaining tolerant individuals have been performed largely by using cotyledon, hypocotyl, and leaf explants. However, few studies reported tomato regeneration using root explants [20-24]. Eggplant (Solanum melongena) belongs to Solanaceae and grown in tropical and semi-tropical climates. Issues like a genetic mismatch between species and infertility of varieties have prevented the development of tolerant varieties against biotic and abiotic damages. To overcome breeding problems in eggplant, advanced biotechnological methods such as tissue culture and plant genetic engineering instead of conventional methods increase the success rate [25]. Eggplant direct shoot regeneration studies were mainly carried out using cotyledon, hypocotyl, and leaf explants. Unlike other explants, stable optimization of direct shoot formation with root explants has not been reported [26-29].

The current study was designed to investigate and develop an optimized regeneration protocol using root node explants in pepper, tomato, and eggplants. Besides, comparative analysis of shoot growth and root elongation using root nodes was performed for the first time with a view to identify the regenerants with superior performance.

\section{Material and Methods}

\section{Plant Material}

In the current study, Ilica pepper (P-Ilica), H2274 tomato (T- H2274) and Aydin Black eggplant (EPAydın Black) cultivars were used as materials.

\section{Seed Sterilization}

Seeds were pretreated with water for $2 \mathrm{hr}$. to remove the protective chemical coating. Surface sterilization of seeds was carried out using 25\% commercial bleach and a few drops of Tween 20 in the laminar cabin for $15 \mathrm{~min}$. Afterward, the surface sterilization process was completed by washing the seeds 5 times $(5$ mins) with distilled water. Sterile seeds were sown on media after drying on blotter paper.

\section{In vitro Regeneration}

Sterilized seeds were germinated on MS media [30] containing $4.44 \mathrm{~g} / \mathrm{L}$ MS salts (Caisson labs, Smithfield, USA), $30 \mathrm{~g} / \mathrm{L}$ sucrose and $5 \mathrm{~g} / \mathrm{L}$ agar (Duchefa Biochemie, Haarlem, The Netherlands) at $24^{\circ} \mathrm{C}$ in dark for 3 days. Germinated seedlings were incubated in a growth cabinet for 15 days at $25^{\circ} \mathrm{C}$ and under $16 / 8 \mathrm{~h}$ photoperiod. Root node explants isolated from in vitro grown seedlings were transferred to a liquid medium containing $\mathrm{MS}+$ Kinetin (Kin) $(4 \mathrm{mg} / \mathrm{L})$. After $24 \mathrm{hr}$ explants were transferred to regeneration media containing different concentrations of cytokinins. Regeneration medium (MS: $4.43 \mathrm{~g} / \mathrm{L}$, sucrose: $30 \mathrm{~g} / \mathrm{L}$, plant agar: $7 \mathrm{~g} / \mathrm{L}$ ) containing different concentrations of BAP (MS-B) (Sigma, Missouri-USA) (0.00, 0.50, 1.00, 1.50, $2.00 \mathrm{mg} / \mathrm{L}$ ), TDZ (MS-T) (Sigma, MissouriUSA) $(0.00,0.50,1.00,1.50,2.00 \mathrm{mg} / \mathrm{L})$ and $\mathrm{GA}_{3}$ (MS-G) (Sigma, Missouri-USA) $(0.00,0.50,1.00$, $1.50,2.00 \mathrm{mg} / \mathrm{L})$. Five explants were cultivated in each magenta box and the experiment was performed in five replications. The Magentas were incubated in a growth chamber at $24^{\circ} \mathrm{C}$ under the $8 / 16 \mathrm{hr}$ photoperiod. Regeneration efficiencies were evaluated after $3^{\text {rd }}$ week.

\section{Plant Acclimatization}

Plants with root development observed were transferred to mixtures containing 2:1 sterilized peat: perlite. Young seedlings were transferred to flowerpots, covered with transparent bags and incubated at 50\% humidity at $25 \pm 2^{\circ} \mathrm{C}$ until well-developed regenerates were obtained.

\section{Statistical Analysis}

All statistical analyzes were done using the IBM SPSS Statistics 22.0 program according to the randomized plot design. Mean values were compared 
a)
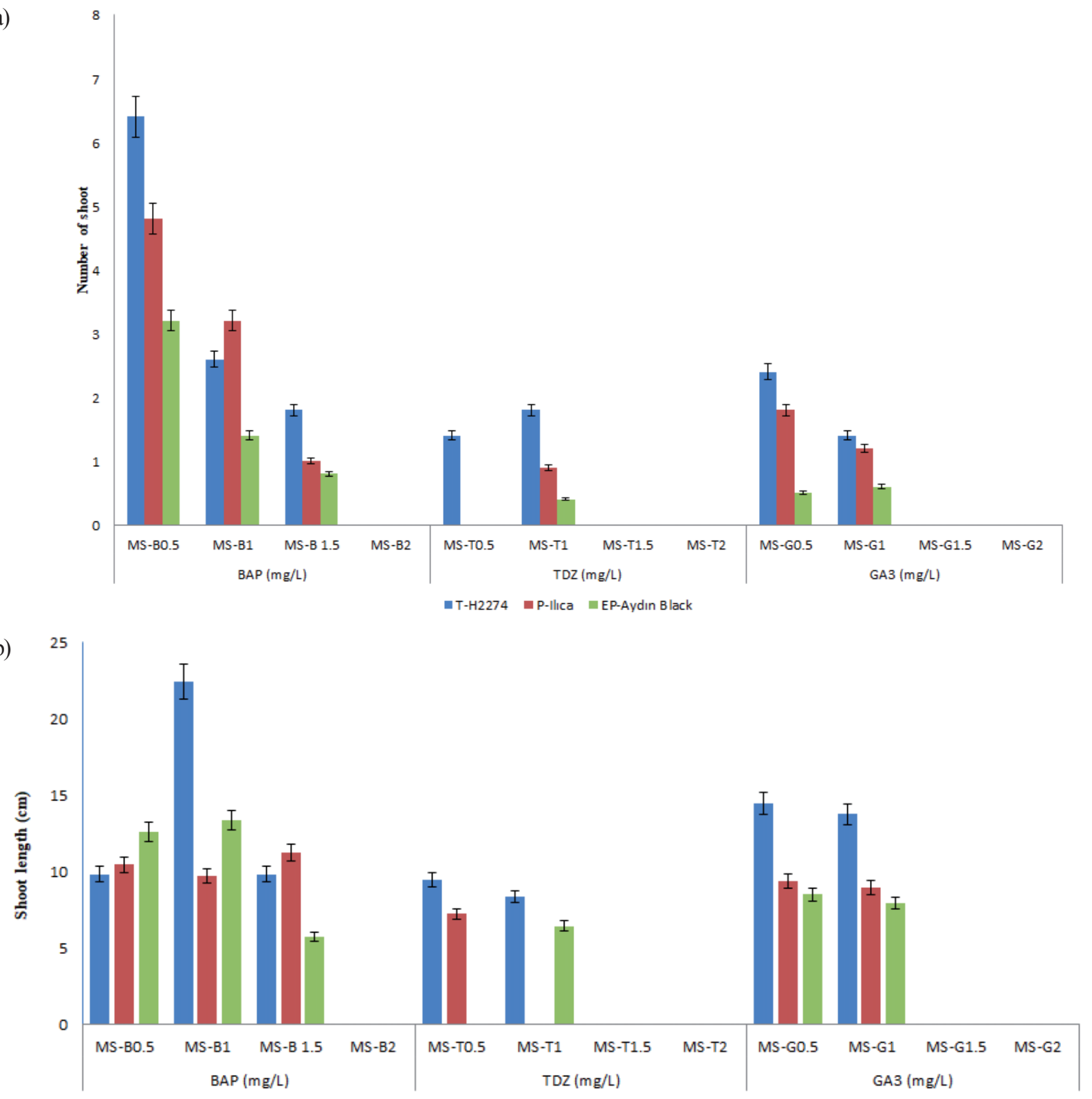

ET-H2274 घP-\|lica EEP-Aydın Black

Fig. 1. a) number of shoot regeneration from root node explant; b) shoot lenght from root node explant.

by ANOVA followed by Tukey posthoc test at 0.05 level of significance.

\section{Results}

\section{Shoot Regeneration}

In the current study, three types of cytokinin hormones were applied (MS-B, MS-G and MS-T) to determine their effects on shoot formation in T- H2274, P-Ilıca and EP- Aydın Black. Maximum shoots regeneration was observed from MS-B (Fig. 3b; Fig. 4c; Fig. 5d). Among the MS-B concentrations, the best shoot formation was recorded for MS-B0.5 followed by MS-B1 and MS-B1.5. No shoot formation was observed in the medium containing MS-B2, while callus formation occurred in the same media (Fig. 1a). In media containing MS-B0.5, the highest shoot number was obtained from T- H2274 with 6.4 per explant followed by EP- Aydın Black with 4.8 and P-Ilıca with 3.2. In media MS-B1, the highest numbers of shoots were obtained from EP-Aydın Black with 3.2 followed by T-H2274 with 2.6 and P-Ilıca with 1.4 (shoot/per explant). In MS-B1.5, 1.8 shoots were obtained from T- H2274, 1 shoot from EP- Aydın Black and 0.8 shoot from P-Ilica (Fig. 1a). 
a)

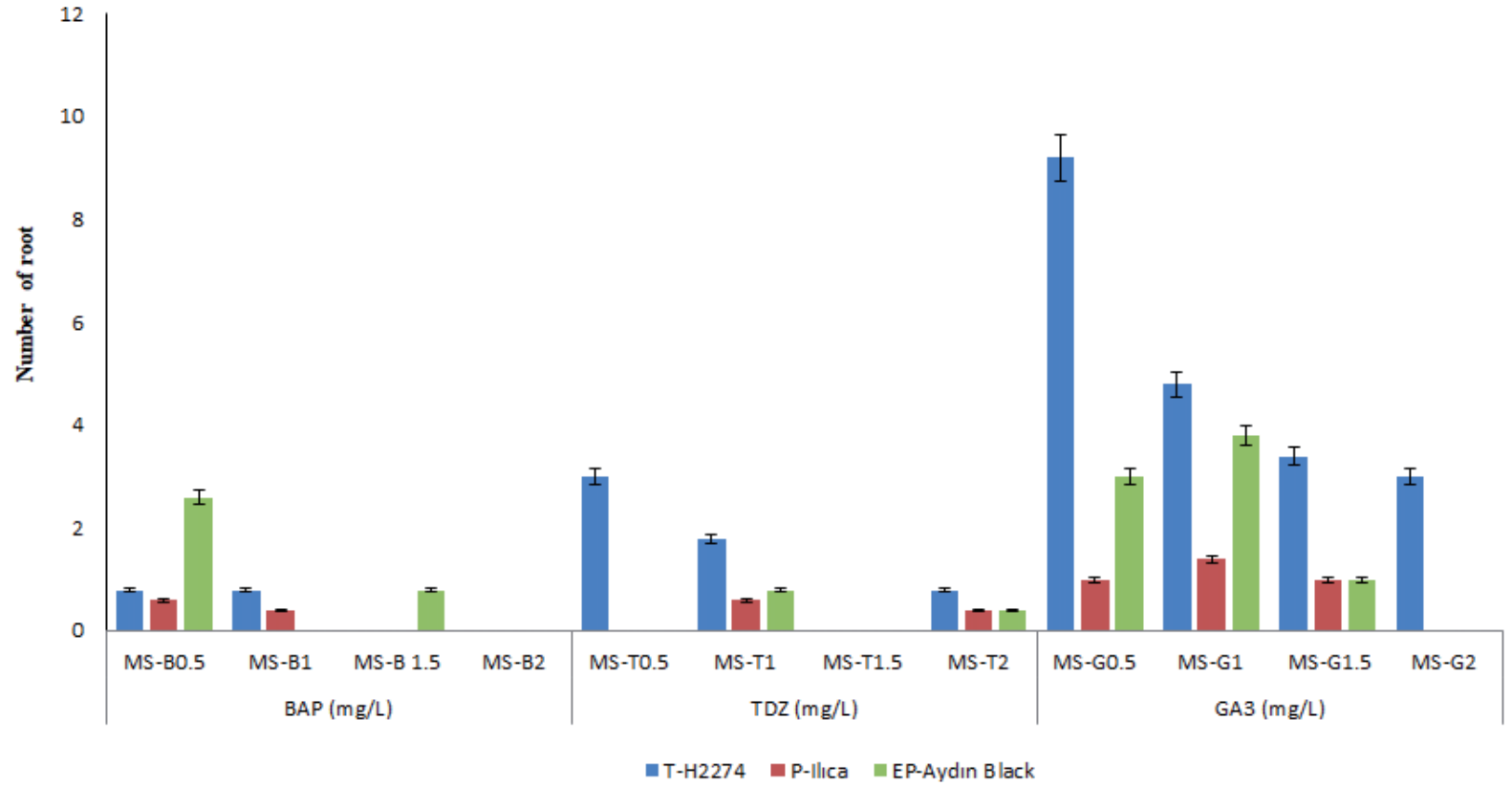

b)

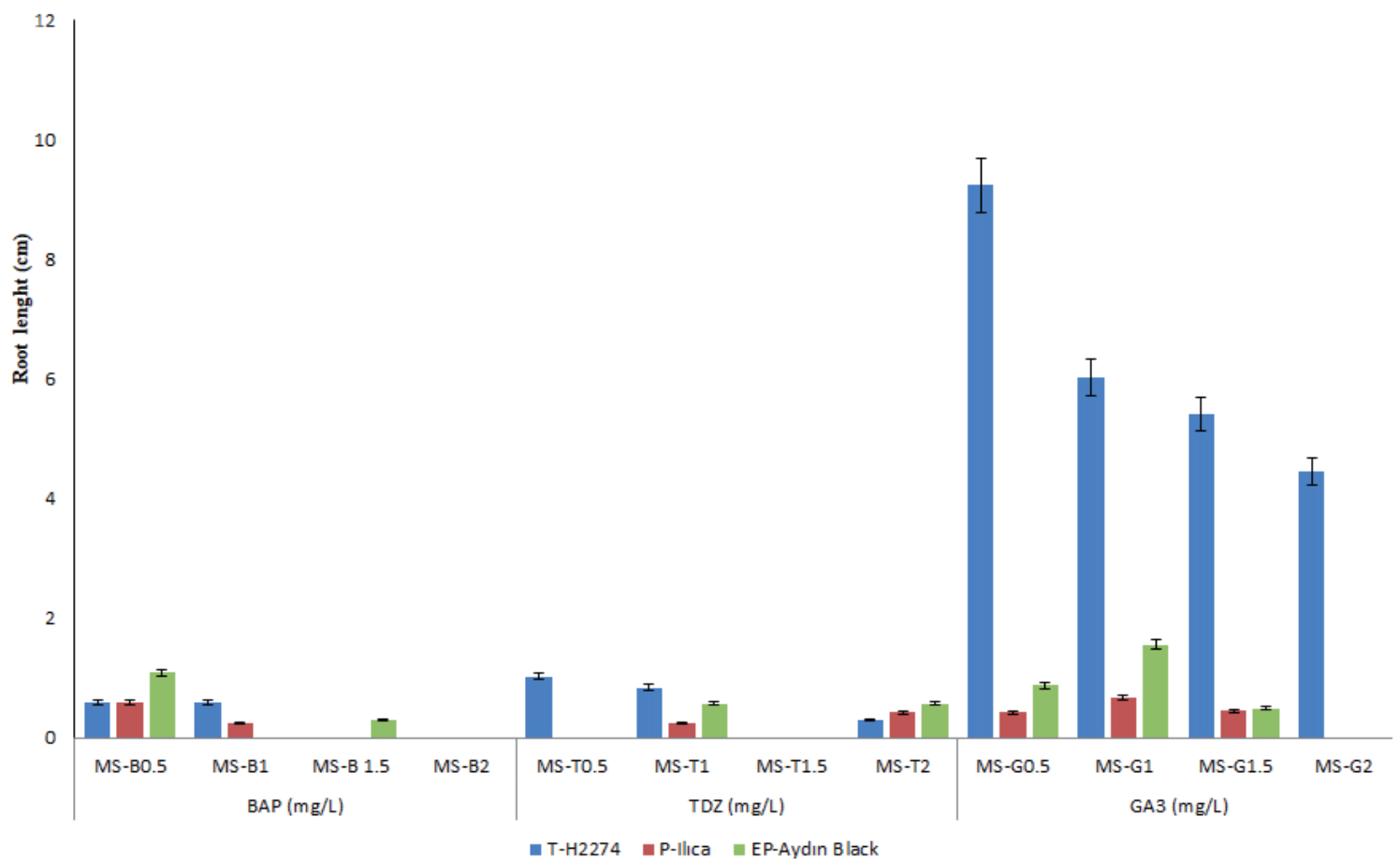

Fig. 2. a) number of root regeneration from root node explant; b) root length from root node explant.

In addition to BAP another plant hormone of cytokinin group i.e., $\mathrm{GA}_{3}$ was applied and tested in terms of shoot formation ability in T- H2274, P-Ilica and EP- Aydin Black. According to the obtained results, for medium MS-G0.5, an average of 2.4 shoots was recorded in T- H2274, 1.8 in EP-Aydin Black and 0.5 in P-Ilica. In the medium MS-G1, the shoot regeneration rate was lower and an average of 1.4 shoot was observed in T- H2274 explant, 1.2 in EP-Aydin Black and 0.6 in P-Ilica.

The MS-T media resulted in the lowest shoot formation in all three vegetable species compared to MS-B and MS-G. In media MS-T0.5 around 1.4 shoots were recorded in T-H2274. At MS-T1, the shoot regeneration was recorded as 1.8 in $\mathrm{T}-\mathrm{H} 2274,0.9$ in EP-Aydın Black and 0.4 in P-Ilıca (Fig. 1a). In all of the media containing high levels of cytokinins, callus formations were observed in the root node explant, which was not be obtained from shoot.

At the end of $6^{\text {th }}$-week shoot lengths of fully-grown plantlets were recorded before they were transferred to soil for acclimatization (Fig. 1b). According to these results, the best shoot length from 3 different cytokinins was observed in T-H2274 i.e., $22.4 \mathrm{~cm}$ in the MS-B1 

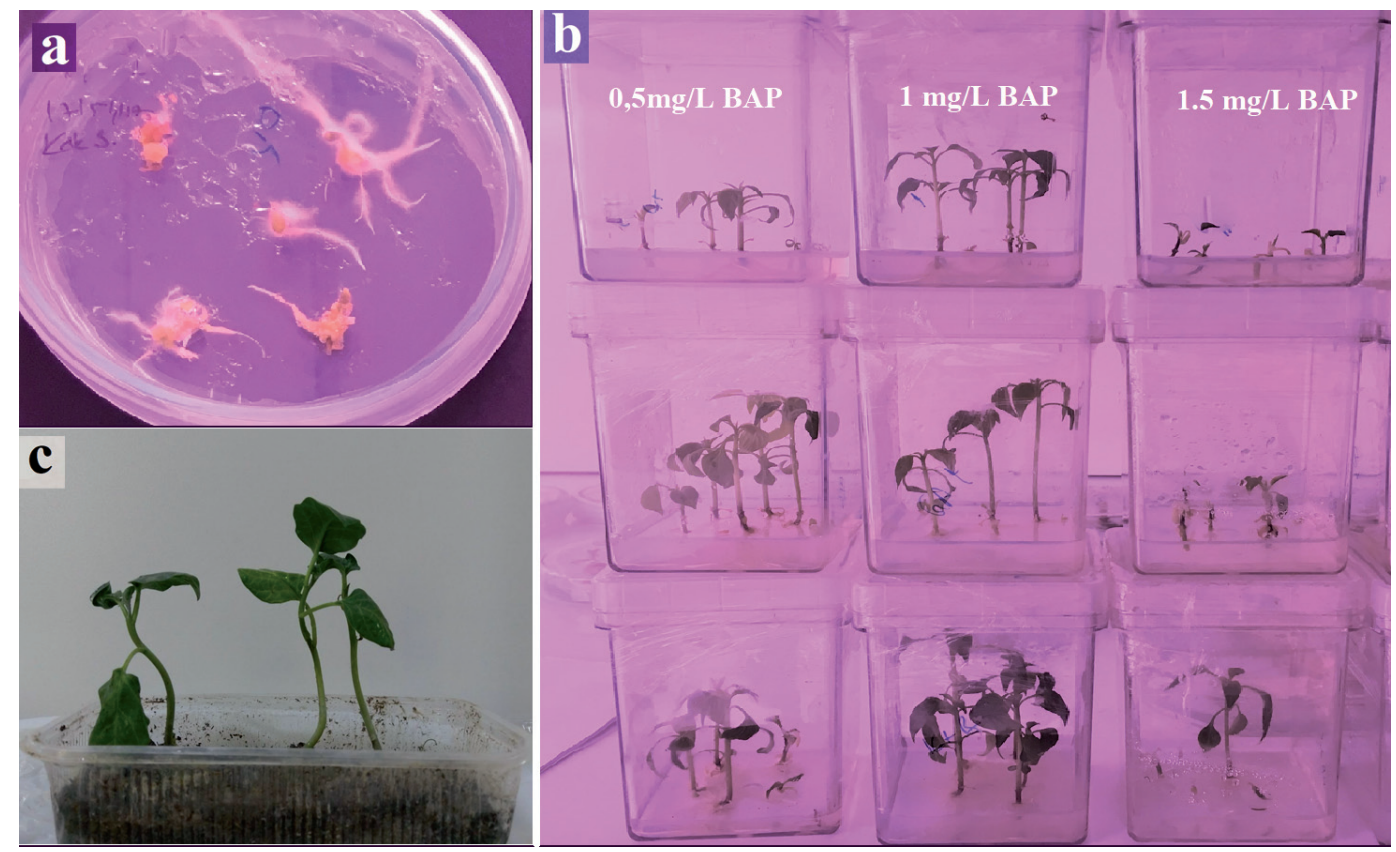

Fig. 3. in vitro plant regeneration from root node explant in pepper

a) pepper explants have root development in cytokinin media; b) shoot development was observed in media with different BAP; c) development of regenerant plants in acclimatization environments
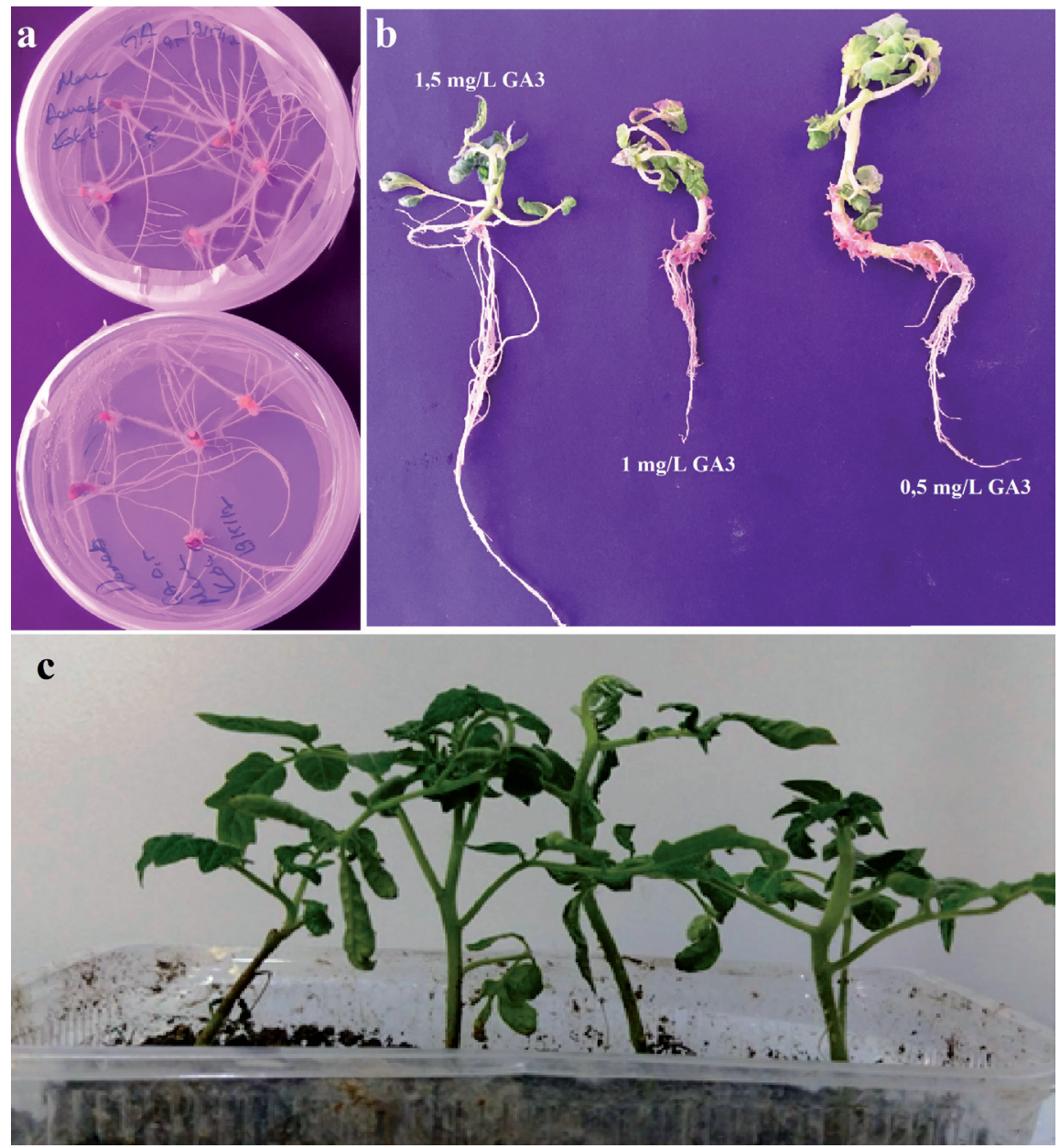

Fig. 4. in vitro plant regeneration from root node explant in tomato

a) root elongation of tomato root node explants in media containing GA3; b) tomato explants have completed the shoot and root regeneration. c) development of regenerant plants in acclimatization environments 

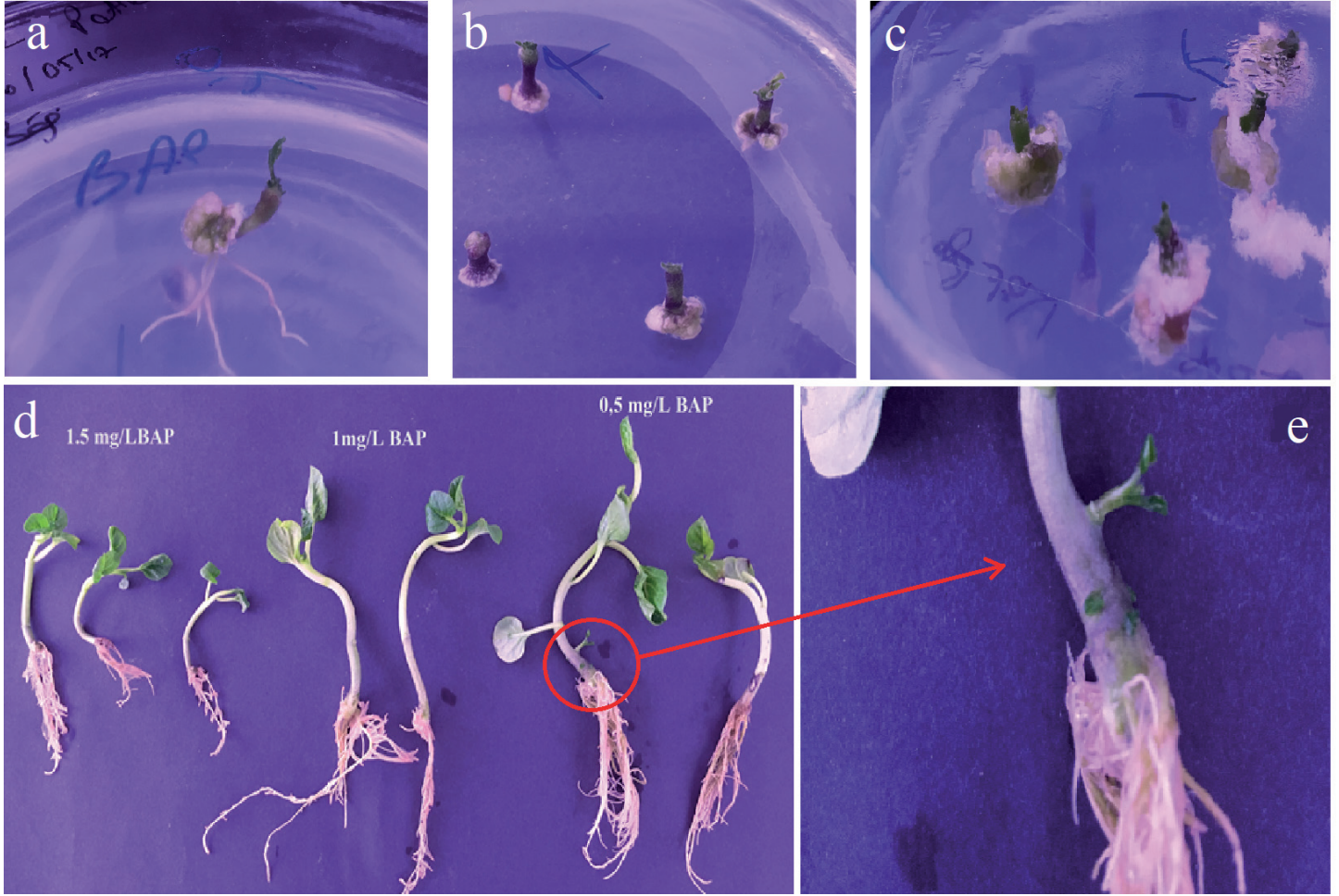

Fig. 5. in vitro plant regeneration from root node explant in eggplant

a) root and shoot regeneration of eggplant explants in BAP media; $b, c)$ shoot regeneration from root node explants in media containing different concentrations of cytokinins; d) last state before acclimatization of plants whose shoot and root regeneration has been completed; e) continued shoot development from the root node explant

media followed by $14.4 \mathrm{~cm}$ (MS-G0.5) and $13.77 \mathrm{~cm}$ (MS-G1) $(p<0.05) \quad$ (Fig. 4c). The variation between MS-B and MS-T, application doses and species was found to be insignificant $(p>0.05)$.

\section{Root Regeneration}

Adventitious root formations by root node explants at the end of the $3^{\text {rd }}$ week in media containing cytokinins are given in Fig. 2a). Among the different cytokinins and application doses used, the most effective adventitious root formation was determined as 9.2 roots in MS-G0.5 in T-H2274 $(p<0.05)$.

The best adventitious root regeneration in eggplant was determined as 3.8 in the MS-G1 medium. No statistically significant variation was found between the root regeneration of MS-G doses in EP-Aydin Black. The best adventitious root regeneration obtained in P-Ilica was recorded as 1.4 roots in MS-G1. Among the different doses of MS-T, root regeneration in 3 species occurred only at MS-T1, with significant variation $(p<0.05)$. In media containing MS-T0.5, among all the plants, the adventitious root formation was observed only in tomato. There is no statistically significant difference in adventitious root formation at different doses of MS-B and among the three species $(p>0.05)$. The lengths of adventitious roots from root node explants in the media containing cytokinin are given in Fig. 2b. Rather than the other two types of cytokinins, it was MS-G that had the most effective influence on root elongation.

According to the other two Solanaceae species, It was determined that $\mathrm{T}-\mathrm{H} 2274$ had the best root elongation capacity in the cytokinins environment (Fig. 4a-b). The best result was obtained from tomato root node explants (average $9.24 \mathrm{~cm}$ root elongation) in the MS-G0.5 medium. Among the three Solanaceae species, no statistical difference was observed in the effects of MS-G1, MS-G1.5 and MS-G2 on root elongation. Similarly, the effects of MS-T and MS-B concentrations on root elongation were insignificant. The difference between the root lengths of P-Ilica and EP-Aydın Black was also statistically insignificant $(p>0.05)$ (Fig. 3a; Fig. 4a; Fig. 5a-c).

\section{Discussion}

\section{Shoot Regeneration}

As it is known, direct regeneration is essential to obtain plants with uniform genetic characteristics. It has been reported that direct regeneration from the explants, without going into the callus formation phase, can help prevent the callus related genetic variations. Therefore, direct regeneration is the most important for gene transformation [31, 32]. Considering this fact, in the current study we have obtained all the shoots from 
root node explants with direct organogenesis without the formation of callus. Also, the root node explants isolated from young seedlings were kept in liquid MS media containing $4 \mathrm{mg}$ / L Kin for $24 \mathrm{hr}$. in the dark and then planted in the media as per experimental design. An inducing factor is essential for the regeneration of tissue or cells isolated from the plant. Although the inducer required for organogenesis is later removed from the environment after a certain period, the growth and development that have started to continue [33].

In our study, we used a high dose of Kinetin for pre-treatment. This treatment was thought to have a positive effect on the formation of shoots from the root node explants. Although many biotechnological studies have been carried out in tomato using root explants, nodal explants and roots are rarely used for shoot regeneration. Besides, these studies did not proceed beyond the experimental dimension $[34,35]$. Compared with eggplant and pepper, the tomato has been identified as the most responsive to shoot regeneration from root nodes. In this study, because of its high conversion potential, the root node explant was used for shoot formation in tomato, pepper and eggplants.

Pepper's success rate and speed in in vitro regeneration are closely related to genotypic features. Genotypically, regeneration is relatively slow and difficult compared to other members of Solanaceae [36]. Although pepper performs efficiently during organogenesis induction in the cytokinin-containing medium, the necessity of an auxin-containing medium for root formation has been reported [17]. In the regeneration study conducted, it was thought that the shoot and root emerging from the existing root explant will provide a significant advantage in the regeneration rate.

A high degree of self-pollination and lack of proper genetic resources in tomatoes is a major problem for breeding. Therefore, genetic diversity is gradually decreasing [37]. It is of great importance to obtain new varieties that help eliminate incompatibility problems between regeneration protocols and Solanaceae species introduced in the current study.

Considering these results, it has been revealed that different plant species have a different rate of regeneration even from a similar explant. Several species of Solanaceae family are the target model species for studying the mechanisms and hormonal interactions that become active in regeneration. Rashid and $\mathrm{Bal}$ [23] reported the use of a hypocotyl explant in tomato, and according to their results, the formation of shoot per explant lasted approximately 8 weeks. The highest shoot was obtained from the medium containing $0.5 \mathrm{mg} / \mathrm{L}$ BAP $+\mathrm{KIN}$ with an average of 3.87. On the other hand, in the current study, a higher regeneration rate was achieved by using root node explants than the hypocotyl. Besides, the lack of an additional rooting step kept the success rate of the procedure even higher and consequently making it a suitable protocol for the tested plants. Jehan and Hassanein [35], reported the somatic embryogenesis from tomato nodal explant and achieved successful results in BAP containing media ( $2 \mathrm{mg} / \mathrm{L}$ BAP - 8.00 number of shoot/explant). Also, it has been reported that the media containing $1 \mathrm{mg} / \mathrm{L}$ IAA for rooting gave the best results and rooting occurred without auxin supplementation. In our study, in addition to obtaining similar values $(0.5 \mathrm{mg} / \mathrm{L}$ BAP - 6.4 of shoot/explant) from root node explants at low BAP levels, root organogenesis occurred in auxin-free media. According to the reported shoot regeneration in eggplant using root explant [26], obtained shoot regeneration from the calluses using MS media with high BAP content. An additional intervention was needed for rooting from the shoots they obtain in the study. In our study, shoot regeneration was carried out as a result of direct organogenesis. Besides, an additional rooting phase was not needed as the shoots performed well during root formation. Similarly, a few researchers had reported obtaining rooting from different eggplant explants in an IBA containing media [38]. According to the report in eggplant regeneration from callus, obtained shoot (average 0.2) in containing a high amount of cytokinin medium [29]. However, in the current study, averages of 4.8 shoots were regenerated in the MS-B0.5 medium with direct organogenesis (without callus). The high regeneration rate in our case can be ascribed to the pre-treatment of explants with high concentrations of KIN for 1 day, which activated the cytokinin response in the tissues.

The current study can be considered the first report for successful direct organogenesis using a root node explant in pepper. In this way, a plant with stable genetic features was obtained for use in biotechnological studies. The number of shoots regeneration from root node explants, in pepper, was observed to be lower than tomato and eggplant. This can be due to the difference in the reaction mechanism of the species. It is thought that this study will contribute in terms of hormonecell interactions in tissue culture studies, regeneration ability of different tissues and development of successful transgenic plant protocols. In the current study, callus formation was observed after the pre-treatment of the explants with Kin before transferring to high cytokinin containing media. However, no shoot formation was recorded from these explants. Callus formation can occur in the presence of pathogen infection, tissue injury, high auxin, or equal auxin-cytokinin hormones in the environment [39]. The callus formation in the root node explant (grown in high cytokinin media) is due to the endogenous auxin in the plant. It has been reported that calluses obtained from the root and hypocotyl explants have many of the structural features of the lateral root meristem [40]. It is predicted that new plants to be produced by using callus-derived callus obtained in our study will cause an increase in its development due to the strong plant nutrient absorption feature of the side root meristem. 


\section{Root Development}

In the study carried out to analyze the endogenous hormones in the plant, the amount of total endogenous cytokinin on the shoots was determined 1.4 times more than the roots. Roots were reported to have higher IAA content than shoots [41]. Free cytokinins in the plant are carried from root to shoots [42]. On the other hand, auxin in the plant is produced in leaf tips [43] and stored in tissues close to the root [44]. In the absence of auxin, regardless of the number of cytokinins in the medium, it has been reported that tomato explants form adventitious roots, due to the accumulation of high independent endogenous auxin in hypocotyl and root cut regions [45, 46]. In our study, high de novo root regeneration was observed especially in tomato which can be linked to the endogenous auxin level. Similarly, Blakesley [42], reported that the ratio of free IAA to total IAA in the root region of young shoots was higher than the elder shoots where rooting has failed. In the current result, it is thought that root regeneration is stimulated by changing the cytokinin balance in young explants. With this viewpoint, this change in cytokinin level resulted in the activation of bound endogenous IAA in tissues and consequently stimulation of root regeneration in eggplant and tomato. It was further reported that the continuous application of an inducer is not required for the continuation of organogenesis and root elongation [33]. Besides, it has been reported that organogenesis and root elongation may be caused regardless of the ambient oxide in the medium, by the activation of genetic indicators due to cutting off the explant [47]. The low root regeneration of the pepper explant may be due to the lack of total IAA and free IAA. Also, activation of the genes responsible for auxin transport may cause this condition [48]. Orlińska and Nowaczyk; in their regeneration study conducted in pepper, they reported that rhizogenesis formation was observed in the auxincontaining media despite the absence of leafy shoots [17]. Bhutia et al; in an in vitro regeneration study conducted with cotyledon using hypocotyl explants, it was reported that root formation was observed 7-8 weeks after transfer of the obtained shoots to the auxin-containing/ non-auxin media [49]. In our study, it is clear that there is an increase in the rate of root regeneration with the occurrence of root development in the early stages of regeneration with the root node explant selected.

The roots obtained from the root node explant in tomato and eggplants were formed as a result of de novo organogenesis. Reported that a similar study [50], de novo organogenesis occurred by re-activating the root tissue obtained from the root explant of the already existing meristematic tissue without the formation of callus. Jehan and Hassanein [35] investigated the effect of tomatoes explant position (horizontal or vertical) in the media. Results revealed that root organogenesis occurred in the explant placed vertically in auxin-free media while no organogenesis reported in horizontally placed explants. In addition to the other issues discussed in our study, the fact that the root node explants are placed vertically in the media is thought to cause de novo root formation by allowing the endogenous auxin hormone in the tissue to move to the lower part of the explant.

From a different perspective. It has been reported that the transport of auxin and cytokinin stopped in this region after the root tissue has been cut and the healing path has been activated [51]. It has also been noted that after the root explant is isolated from the plant, there are genetically significant similarities between leaf and root vein development on this tissue [51]. When considered from this perspective, it is thought that, together with all other possibilities, genetic induction may also be involved in in vitro regeneration obtained from root tissue.

\section{Conclusion}

The current study was conducted to investigate the regenerative capabilities from root node explants of three different Solanaceae. Shoot regeneration was successfully performed using the root explant. Among the species, the best shoot regeneration rate was recorded for tomato, pepper, and eggplant respectively. Among the cytokinin hormones, the most effective hormone in shoot regeneration was determined as $0.5 \mathrm{mg} / \mathrm{L}$ BAP. The shoot length of the newly regenerated plants varied according to the plant species and cytokinin content. For the Solanaceae species, the best hormone in terms of root development and length was determined as GA3. The best root development and elongation ability were observed in tomato, eggplant, and pepper respectively. This study reveals important results that can be targeted in determining hormonal changes in root and shoot regeneration. For these reasons, the current successful and effective regeneration method; will serve important issues such as determining physiological, morphological, and molecular changes in root and shoot regeneration.

\section{Author Contribution Statement}

$\mathrm{AE}$ and $\mathrm{MCCO}$ designed and outlined the research. $\mathrm{MCCO}$ and MDK conducted the experiments. EO, MM, SA and MÇO analyzed the data, drafted and edited the manuscript and analyzed the data.

\section{Acknowledgements}

We would like to thank Dr. Canan Yüksel Özmen for her technical support in tissue culture studies.

\section{Conflict of Interest}

The authors declare no conflict of interest. 


\section{Data Availability}

The data from the study were presented in the text and tables and figures.

\section{References}

1. GUBIS J., LAJCHOVÁ Z., FARAGÓ J., JUREKOVÁ $Z$. Effect of growth regulators on shoot induction and plant regeneration in tomato (Lycopersicon esculentum Mill.). Biologia-Bratislava, 59 (3), 405, 2004.

2. SHARMA P., SRIVASTAVA D. In vitro plant regeneration from cotyledon and hypocotyls tissues of tomato (Solanum lycopersicum L. cv. Solan Vajr). Vegetos, 27 (3), 151, 2014.

3. DEB G., SULTANA S., BHUIYAN M.S.U., SARKER K.K., PAPRY A.S. In vitro plant regeneration of wild eggplant (Solanum sisymbriifolium) to produce large number of rootstocks for tomato grafting. Journal of Advanced Biotechnology and Experimental Therapeutics, 2, 65, 2019.

4. CHAUDHURI K., GHOSH B., JHA S. The root: a potential new source of competent cells for high-frequency regeneration in Tylophora indica. 22 (10), 731, 2004.

5. HEGDE V., PARTAP P.S., YADAV R.C. In vitro regeneration of Capsicum (Capsicum annuum L.) from cotyledon explants. International Journal of Current Microbiology and Applied Sciences, 6 (5), 225, 2017.

6. OO P.C., LEE Z.H., CHIN C.K., SUBRAMANIAM S., CHEW, B.L. Shoot Induction in White Eggplant (Solanum melongena L. Cv. Bulat Putih) using 6-Benzylaminopurine and Kinetin. Tropical life sciences research, 29 (2), 119, 2018.

7. POCKOVSKA M., TRAJKOVA F., KOLEVA GUDEVAI L. Evaluation of androgenic competence of different pepper, tomato and eggplant genotypes. in Book of Proceedings/X International Scientific Agriculture Symposium" Agrosym 2019". Faculty of Agriculture, East Sarajevo, Bosnia \& Hercegovina. 525, 2019.

8. CHOWAŃSKI S., ADAMSKI Z., MARCINIAK P., ROSIŃSKI G., BÜYÜKGÜZEL E., BÜYÜKGÜZEL K., BUFO S.A. A review of bioinsecticidal activity of Solanaceae alkaloids. Toxins, 8 (3), 60, 2016.

9. SERNA F.J., CORREA J.A. Extractos de hojas de tomate Lycopersicon esculentum como fagoinhibidores de Atta cephalotes. 21 (3), 142, 2003.

10. SAMUELS J. Biodiversity of food species of the Solanaceae family: a preliminary taxonomic inventory of subfamily Solanoideae. Resources. 4 (2), 277, 2015.

11. GEBHARDT C. The historical role of species from the Solanaceae plant family in genetic research. Theoretical and Applied Genetics, 129 (12), 2281, 2016.

12. BUI H.H., SERRA V., PAGÈS L. Root system development and architecture in various genotypes of the Solanaceae family. Botany. 93 (8), 465, 2015.

13. KHAN H., SIDDIQUE I., ANIS M. Thidiazuron induced somatic embryogenesis and plant regeneration in Capsicum annuum. 50 (4), 789, 2006.

14. DO REGO E.R., DO RÊGO M.M., FINGER F.L. Production and breeding of chilli peppers (Capsicum spp.). Springer. 2016.

15. GROZEVA S., TODOROVA V. In vitro regeneration in pepper (Capsicum annuum L.) and characterization of plant-regenerants. Electronic Journal of Biology. 11 (1), 17, 2015.

16. HEIDARI-ZEFREH A.A., SHARIATPANAHI M.E., MOUSAVI A., KALATEJARI S. Enhancement of microspore embryogenesis induction and plantlet regeneration of sweet pepper (Capsicum annuum L.) using putrescine and ascorbic acid. Protoplasma. 256 (1), 13, 2019.

17. ORLINSKA M., NOWACZYK P. In vitro plant regeneration of 4 Capsicum spp. genotypes using different explant types. Turkish Journal of Biology. 39 (1), 60, 2015.

18. KIM H., LIM J. Leaf-induced callus formation in two cultivars: hot pepper 'CM334'and bell pepper 'Dempsey'. Plant signaling \& behavior. 14 (7), 1604016, 2019.

19. DU Y.D., CAO H.X., LIU S.Q., GU X.B., CAO Y.X. Response of yield, quality, water and nitrogen use efficiency of tomato to different levels of water and nitrogen under drip irrigation in Northwestern China. Journal of integrative agriculture. 16 (5), 1153, 2017.

20. MOGHAIEB R.E., SANEOKA H., FUJITA K. Plant regeneration from hypocotyl and cotyledon explant of tomato (Lycopersicon esculentum Mill.). 45 (3), 639, 1999.

21. VIKRAM, G., SRIKANTH, K., SWAMY, B. Effect of plant growth regulators on in vitro organogenesis in cultivated tomato (Solanum lycopersicum L.). 1 (4), 263, 2011.

22. MAMIDALA P., NANNA M.B. Effect of genotype, explant source and medium on in vitro regeneration of tomato. 3, 45, 2011.

23. RASHID R., BAL S.S. Effect of hormones on direct shoot regeneration in hypocotyl explants of tomato. 2 (1), 70, 2010.

24. PERES L.E., MORGANTE P.G., VECCHI C., KRAUS J.E., VAN SLUYS M.A. Shoot regeneration capacity from roots and transgenic hairy roots of tomato cultivars and wild related species. 65 (1), 37, 2001.

25. SHIVARAJ G., RAO S. Rapid and efficient plant regeneration of eggplant (Solanum melongena L.) from cotyledonary leaf explants. 2011.

26. FRANKLIN G., SHEEBA C., LAKSHMI SITA G. Regeneration of eggplant (Solanum melongena L.) from root explants Plant. 2004.

27. SARKER R.H., YESMIN S., HOQUE M.I. Multiple shoot formation in eggplant (Solanum melongena L.). 16 (1), 53, 2006.

28. MIR K.A., DHATT A.S., SANDHU J.S., GOSAL S.S. Genotype, explant and culture medium effects on somatic embryogenesis in eggplant (Solanum melongena L.). 49 (3), 182, 2008.

29. RAY B.P., HASSAN L., SARKER K. In vitro cultivation and regeneration of Solanum Melongena (L.) using stem, root and leaf explants. 1 (1), 49, 2011.

30. MURASHIGE T., SKOOG F. A revised medium for rapid growth and bio assays with tobacco tissue cultures. Physiologia plantarum, 15 (3), 473, 1962.

31. EVANS D., BRAVO J. Phenotypic and genotypic stability of tissue cultured plants, in Tissue culture as a plant production system for horticultural crops. Springer. 73, 1986.

32. SRIVATANAKUL M., PARK S.H., SANDERS J.R., SALAS M.G., SMITH R.H. Multiple shoot regeneration of kenaf (Hibiscus cannabinus L.) from a shoot apex culture system. 19 (12), 1165, 2000.

33. MOHNEN D., Novel experimental systems for determining cellular competence and determination, in Biology of adventitious root formation. Springer. 87, 1994. 
34. BHATIA P., ASHWATH N., SENARATNA T., MIDMORE D. Tissue culture studies of tomato (Lycopersicon esculentum). 78 (1), 1, 2004.

35. JEHAN S., HASSANEIN A., Hormonal requirements trigger different organogenic pathways on tomato nodal explants. 4 (11), 2118, 2013.

36. KUMAR S. A review on ethno-medicinal properties and plant tissue culture of high value solanaceous plants. J. Phytol. Res 30 (2), 63, 2017.

37. SHARMA U., SINGH P., RAI N.P. Regeneration study in Solanum lycopersicum.

38. SIDHU M., DHATT A., SIDHU G. Plant regeneration in eggplant (Solanum melongena L.): A review. 13 (6), 714, 2014.

39. IKEUCHI M., SUGIMOTO K., IWASE A. Plant callus: mechanisms of induction and repression. 25 (9), 3159, 2013.

40. ATTA R., LAURENS L., BOUCHERON-DUBUISSON E., GUIVARC'H A., CARNERO E., GIRAUDATPAUTOT V., CHRIQUI D. Pluripotency of Arabidopsis xylem pericycle underlies shoot regeneration from root and hypocotyl explants grown in vitro. 57 (4), 626, 2009.

41. TRIFUNOVIĆ-MOMČILOV M., MOTYKA V., DRAGIĆEVIĆ I.Č., PETRIĆ M., JEVREMOVIĆ S., MALBECK J., SUBOTIĆ A. Endogenous phytohormones in spontaneously regenerated Centaurium erythraea Rafn. plants grown in vitro. Journal of Plant Growth Regulation 35 (2), 543, 2016.

42. BLAKESLEY D. Auxin metabolism and adventitious root initiation, in Biology of adventitious root formation. Springer. 143, 1994.

43. ALONI R., SCHWALM K., LANGHANS M., ULLRICH C.I. Gradual shifts in sites of free-auxin production during leaf-primordium development and their role in vascular differentiation and leaf morphogenesis in Arabidopsis Planta. 216 (5), 841, 2003.

44. SCARPELLA E., MARCOS D., FRIML J., BERLETH T. Control of leaf vascular patterning by polar auxin transport. Genes \& development 20 (8), 1015, 2006.

45. ASHAKIRAN K., SIVANKALYANI V., JAYANTHI M., GOVINDASAMY V., GIRIJA S. Genotype specific shoots regeneration from different explants of tomato (Solanum lycopersicum L.) using TDZ. 1 (2), 107, 2011.

46. KUROHA T., KATO H., ASAMI T., YOSHIDA S., KAMADA H., SATOH S. A trans-zeatin riboside in root xylem sap negatively regulates adventitious root formation on cucumber hypocotyls. 53 (378), 2193, 2002.

47. MARHAVÝ P., MONTESINOS J.C., ABUZEINEH A., VAN DAMME D., VERMEER J.E., DUCLERCQ J., BENKOVÁ, E. Targeted cell elimination reveals an auxinguided biphasic mode of lateral root initiation. 30 (4), 471, 2016.

48. HEISLER M.G., HAMANT O., KRUPINSKI P., UYTTEWAAL M., OHNO C., JÖNSSON H. MEYEROWITZ E.M. Alignment between PIN1 polarity and microtubule orientation in the shoot apical meristem reveals a tight coupling between morphogenesis and auxin transport. PLoS biology. 8 (10), 2010.

49. BHUTIA K.L., MEETEI N., KHANNA V. In vitro direct regeneration of Dalle Khursani (Capsicum annum) from salicylic acid treated explants. Journal of Pharmacognosy and Phytochemistry. 7 (2), 1008, 2018.

50. ZELCER A., SOFERMAN O., IZHAR S. Shoot regeneration in root cultures of Solanaceae. 2 (5), 252, 1983.

51. MELNYK C.W., Plant grafting: insights into tissue regeneration. Regeneration. 4 (1), 3, 2017. 